\title{
„Az Alföld sajátságosan paradox hely..." Interjú Csatári Bálinttal
}

\section{"The Great Hungarian Plain is a paradoxical place" Interview with Bálint Csatári}

\author{
BARTA GYÖRGYI
}

\begin{abstract}
BARTA Györgyi: kutató professzor emerita, MTA Közgazdaság- és Regionális Tudományi Kutatóközpont, Regionális Kutatások Intézete, Budapest; barta@rkk.hu CSATÁRI Bálint: nyugdíjas, MTA Közgazdaság- és Regionális Tudományi Kutatóközpont, Regionális Kutatások Intézete, Kecskemét; csatbal@rkk.hu
\end{abstract}

Györgyi BARTA: research professor emerita, Institute for Regional Studies, Centre for Economic and Regional Studies, Hungarian Academy of Sciences, Budapest; barta@rkk.hu

Bálint CSATÁRI: retiree, Institute for Regional Studies, Centre for Economic and Regional Studies, Hungarian Academy of Sciences, Kecskemét; csatbal@rkk.hu

\section{Hogyan lettél Alföld-kutató?}

Nem tudom, hogy pontosan ez-e a helyes kifejezés. Inkább geográfus vagyok és településföldrajzos, illetve tanár, akinek pályája során - sok kiváló kollegával együttmüködve - lehetősége adódott arra, hogy többször is Alföld-kutatások témavezetője lehessen. De ha csak annyit árulok el az életrajzomból, hogy Karcagon születtem, egy bihari faluban, Zsákán nőttem fel, Berettyóújfaluban jártam gimnáziumba, Szegeden végeztem az egyetemet, majd Tóth József aspiránsaként heti rendszerességű békéscsabai szakmai konzultációk után, Enyedi György hívására költöztünk Kecskemétre, s így szűkebb családom öt tagja az Alföld öt különböző településén - zömmel mezővárosában - született, akkor ebből lehet, hogy az is következik, hogy számomra eleve elrendelt volt ez a feladat. Azt hiszem, hogy - egyetértve békéscsabai kollegáim remek interjújában (Timár et al. 2012) foglaltakkal - itt, a periférián különösen fontos volt, és szerintem az ma is, hogy feltegyük azokat a tudományos kérdéseket, amelyekre a válaszokat keresve segíthetünk a régió életének jobbításában. Ezt tették - a már emlegetett tudósokon túl - Tessedik Sámueltől Mendöl Tiborig, Erdei Ferenctől Kaán Károlyon át Beluszky Pálig nagyon sokan. Több - a régió felemelkedését illetően inkább kevesebb - sikerrel. Különben a földrajz mindig nagyon érdekelt, a mentális térképezést már évtizedekkel azelőtt „gyakoroltam”, mielőtt kutatóként megtudtam, mi is az. Nagyszerü tanáraim és mestereim voltak. Nekik so-

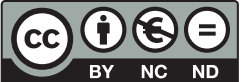


kat köszönhetek a pályám alakulásában. Ők - többen is - ösztönöztek, segítettek, és persze vonzó példát is mutattak, hogy legyek én is tanár, geográfus és Alföld-kutató.

Miket emelnél ki életed, pályád fontosabb eseményeiból, müveiból?

Doktori értekezésemet 1975-ben Szeged járás tanyarendszeréből írtam, Szegeden, Krajkó Gyula professzor tanszékén, részben a tanyáiktól méltatlanul megfosztott nagykun őseim emlékének is adózva. Akkor még nem sejtettem, hogy ez az igazán alföldi és ,vérbeli” településföldrajzi téma szinte egész életpályámat végigkíséri. Részben az 1980-as évek közepén általunk végzett kiskunsági, majd alföldi tanyakutatások nyomán oldották fel négy évtized után az általános külterületi (tanyai) építési tilalmat, és még 2005-ben is sikerült egy igazán nagy léptékű tanyakutatást elvégezni fiatal kollegáimmal együtt (www. alfoldinfo.hu/tanyakutatas), amely után manapság már „célzott” alföldi tanyaprogramok is futnak az Alföld megyéinek településein. Természetesen legalább ilyen fontos volt számomra a két - a részt vevő kutatók, szakértők számát és az akkori viszonyok között a megbízás összegeit tekintve is - jelentős Alföld-kutatás. Különösen a második, az MTA stratégiai kutatási programjaihoz kapcsolódó kutatási projekt volt nagyon fontos, mert - mint békéscsabai kollegáim is elmondták a Tér és Társadalomban - sok fiatal kolléga minősítését és több tudományos könyv megjelenését is köszönhettük ennek a programnak. Nem volt könnyü eleget tenni a kemény feltételeknek, de mondhatom, igazi tudományos műhellyé akkor váltunk, $s$ a végén 12 kutatói státusz „formájában” intézetünk költségvetési alapfinanszírozásához csatolták az összeg egy részét. Akkor még azt hittük, hogy hosszú távon szükség lesz az adott térségek szisztematikus és magas színvonalú regionális, területi és vidékkutatására.

Életed fö müvének tekinted tehát a Regionális Kutatások Központján belül az Alföldi Tudományos Intézet megszervezését, vezetését, bevezetését a tudományos köztudatba?

Érdekes kérdés, hogy mi tekinthető egy kutató fő művének. Talán igaza volt mesteremnek, Tóth Józsefnek, aki szintén a Tér és Társadalomban megjelent visszaemlékező interjújában (Bögre, Kovács, Tóth 2013) a békéscsabai Alföldi Kutatócsoport elindítását tekintette pályája egyik legfontosabb tettének, mondhatni „művének”. Mikor annak alapítása után egy szük évtizeddel (1982-ben) Kecskeméten nekem is lehetőségem nyílt hasonló léptékủ feladatra, még nem gondoltam (gondolhattam), hogy lesz rendszerváltozás, s az egykor Szegeden müködő, Klebelsberg Kuno által kezdeményezett Alföldi Tudományos Intézet újjászervezésére is lehetőséget kapok. Nagyon szép feladat volt, valódi tudományos és tudományszervezői kihívás. De a sikerek főleg a kiváló fiatal kollektíva szoros és erős együttműködésének köszönhetők. Érdemes kiemelni, hogy akkortájt az Alföld regionális problémáinak hiteles tudományos feltárására is komoly igény mutatkozott - mind kormányzati, mind a formálódó megyei és helyi önkormányzati 
szinteken. És valóban ma is nagy dolognak tartom, hogy Kosáry Domokos vezetésével az MTA elnöksége is megvitatta az Alföld helyzetéról készült tudományos téziseinket és fejlesztési ajánlásainkat (1993). Az már persze e dolog másik oldala, amiről Sándor Iván írt: „Évszázados tapasztalat, hogy (hazánkban) a szellem teljesítményei-ajánlatai füstbe mennek. Szerencsés esetben az utólagos összegzésekben, korértelmezésekben van szerepük. Tegyük hozzá: az utólagosságokban gazdag a magyar gondolkodás." (Sándor 2013, 12.)

Ezek igazán súlyos állitások. Ennek ellenére hogyan itéled meg 2015-ból visszatekintve az Alföldi Tudományos Intézet irányitásod alatt megszületett fóbb tudományos eredményeit? A békéscsabai és a kecskeméti alföldi kutatócsoportok munkatársai a Regionális Kutatások Központja interdiszciplináris szellemiségü, korát messze megelőzően modern hálózati rendszerekkel szervezett, pezsgő tudományos életű intézetében leltek új otthonra 1984-ben. Bővült a tudományos palettánk, jellemzővé vált a megközelítések sokfélesége. Olyan új témákról készülhettek disszertációink, mint az akkor még szinte ismeretlen fenntarthatóságról, a természet és a társadalom viszonyának történeti változásairól, a rekreáció geográfiájáról, vagy a világ akkori városföldrajzi szakirodalmának hazai és alföldi adaptációjaként a szuburbanizációról, sőt már a bankfiókrendszer kiépülését is vizsgálhattuk a régióban (Csordás 1993; Lengyel 1994; Rácz 1993; Timár 1999).

Az intézet szervezeti bővülése mellett (az azóta sajnos felszámolt szolnoki és debreceni csoportokra gondolok) a tudományos fejlődés szempontjából döntő és szerintem nagy lépés volt, hogy az új, fontos témák már modern geográfiai témák voltak, s azok műveléséhez először a nemzetközi szakirodalom elméleti és módszertani adaptációját végeztük el, majd ezt a lépést követte az alföldi régió kutatása - mintegy okosan és hasznosan szervezett „esettanulmányként”. Így kutattuk később közösen - az egész akkori kollektíva - a várossikert, alföldi nézőpontból, vagy egyénenként, illetve kisebb csoportokban a környezettudatosságot, az információs és hálózati társadalom vagy az új, szolgáltató gazdaság területi terjedésének jellemzőit, s indultak el például a határ menti, az integrált vidék- és a genderkutatások. Bő tizenöt esztendő kellett ahhoz, hogy az alapés alkalmazott kutatásaink „összeérjenek” (Baranyi 1999; Csatári, Farkas 2007; Kovács 2005; Nagy E. 2002; Nagy G. 2003; Timár 2005; Timár, Velkey 2003).

Végül, de nem utolsósorban nagyon fontos eredménynek tartom a bővülő nemzetközi kapcsolatainkat, kiemelve a lengyel akadémiai társintézetet, az elnyert ösztöndíjakat, a nemzetközi szemináriumokat, a kritikai földrajzi világkongresszust Békéscsabán és a különböző nemzetközi projektekben való részvételt is (Duró 1999; Timár 2003).

És a saját kutatási eredményeid közül mit emelnél ki?

A már említett tanyakutatásokon túlmenően talán a vidékföldrajz iránti érdeklődésem bővülése hozott jelentősebb sikert, eredményt. Ezek közül néhá- 
nyat külföldön is publikálni tudtam. Fontos megemlítenem, hogy az 1990-es évtized elején Kecskeméten létrehozott RKK-s számítóközpontunk lehetővé tette - akkor ez „vidéken” még nagy ritkaságnak számított -, hogy a legmodernebb eszközökkel és módszerekkel dolgozzunk például az akkor formálódó kistérségek földrajzi tipizálásának feladatain, a vidéki tér pontos definiálásán, illetve az alföldi régiók esetenként markánsan különböző térfolyamatainak elemzésén. Enyedi György külön is kiemelte egyszer, egy RKK-s intézeti napon, hogy milyen fontosnak tartja azokat a kecskeméti fiatal kollegáimmal együtt szerkesztett kis köteteinket, amelyek a magyar vidék egy-egy sajátos problémáját járták körül (természetvédelem, perifériaproblémák, a vidék az információs társdalomban vagy - az alföldi problémákra is visszautalva - a Tisza-vidék problémái és fejlesztési lehetőségei).

Végül, visszatekintve, sőt néha az intézetbe bejárva s rendezgetve kézirataimat, két dolog biztosan a kevésbé sikeres listára kerülne. Rengeteg, vagy kis túlzással megszámlálhatatlan olyan külső megbízásos munkát készítettünk, amelyek ahhoz kellettek, hogy az MTA által juttatott béreinkhez és azok járulékaihoz minden évben az alkalmazott tudományos munkánkkal „megtermeljük” a kutatóintézet tényleges működésének rezsiköltségét. Ezekről és a „rendesen megjelent” publikációinkról a húsz éves jubileumunkra Törökné Gémes Tünde páratlanul érdekes bibliográfiát készített 2002-ben (Törökné Gémes 2002). Ha ebbe és a kéziratokba néha belenézek, akkor egyértelműen látszik, hogy nagyon sok, s ma is úgy ítélem, hogy valóban értékes eredményünk soha nem jelent meg „rendesen”. Mert készíteni kellett rögtön a következő kmb-t (azaz külső megbízásos munkát) ahhoz, hogy a gépkocsi benzinköltsége meglegyen, hogy újra kimehessünk a terepre, hogy adatokat gyüjtsünk vagy vásároljunk. Ez az egyre abszurdabb helyzet tette lehetetlenné azt is, hogy néhány témámat (pedig OTKA-pályázatokat is nyertem ezekre) igazán rendesen befejezhessem (kisvároskutatás, az emberi identifikáció változó földrajzi terei című téma kutatása). Persze azt is kudarcnak tartom „kissé”, hogy nem lettem az MTA doktora.

\section{S van-e olyan dolog, ami e tekintetben esetleg kárpótolt?}

Igen. Úgy gondolom és érzem, hogy az egyetemi oktatás mindig nagy örömet okozott, s magam sokkal inkább tanárnak, mint „tudósnak” tartom magam. Tanítványaim (különös tekintettel a már több mint tíz, kandidátusi, doktori és PhDfokozatot elértekre) mindig igényes felkészülésre és jó előadások megtartására sarkalltak, s arra, hogy örökös önkontrollal tegyem a dolgom. Több mint negyven évet töltöttem a katedrán. Hetet középiskolában. Akkori bihari földrajz szakköröseim közül Rácz Lajos az MTA doktora, egyetemi tanár, Csordás László, kandidátus szintén a Szegedi Tudományegyetemen tanít. És egy bő évtizedet Kecskeméten is együtt dolgoztunk. Néhány doktoriskolai növendékem pedig olyan témákat művelt, szerencsére és némi ösztökélésemre, amelyeket én hajdan nem tudtam elvégezni. Még mindig van négy aktív doktorandusz növendékem. 
Az RKK-ból való visszavonulásod után mivel foglalkozol?

Talán mielőtt erre válaszolnék, legalább egy bővített mondatban magáról az intézetből történt visszavonulásomról is szólni szeretnék. Annál pontosabban, mint ahogy a békéscsabai kollégáim fogalmaztak rólam a TéT-beli interjújukban (Timár et al. 2012), én sem tudok: kényszerűség volt. Mert azt hiszem, emberileg és lelkileg nem tudtam volna azokhoz az - egyértelműen szellemi és tudományos értékek rombolásával is járó - átszervezésekhez asszisztálni, amelyek előjeleit már láttam. Meggyőződésem, hogy tudomány-, nemzet- és területpolitikai hiba, hogy ne mondjam bűn volt az RKK durva átszervezése és kutatóhálózatának gyengítése (mikor az egész világ a hálózatokban fejlődik!). Az Alföldnek és a Dunántúlnak is hosszú távon igen nagy szüksége lesz (vagyis lenne) majd azokra a világon és a magyar tudományosságban is nélkülözhetetlen eredményekre, amelyek a globálissal szemben - vagy éppen annak különbözo” „hullámain" - a lokális, illetve a regionális megoldásokat keresik és találják meg. Azaz a táj, a környezet fenntartható használatának modellezésében, a mező- és élelmiszergazdaság regionális „rehabilitációjában”, a város-vidék viszonyok alföldi megújításában. Szomorúan látom például, hogy az Alföldre remekül adaptálhatónak ítélhető, s az EU által ajánlott új CLLD - azaz a városok és vidékeik szervezett közössége által irányított - helyi fejlesztési forma sem kellett igazán nekünk, pedig ennek alkalmazása érdemben hozzájárulhatott volna az e sajátságos régióban jellemző súlyos területi társadalmi konfliktusok (periféria, szegénység stb.) feloldásához. Biztos vagyok benne, hogy a problémák megoldásához szükséges elemzéseket és diagnózisokat most is és a jövőben is rendre meg kell(ene) írnia az Alföld professzionális kutatóinak. De úgy tünik, hogy nálunk ma a területi fejlesztés szinte teljes mértékben centralizált. A helyi fejlesztések pedig szinte csak arról szólnak, hogy bármi áron európai uniós pályázati forráshoz jussanak. Bárminőhöz, akár szükség van rá, akár nincs. Gyakori, hogy bizonyos beruházások, illetve fejlesztések azok externális térbeli hatásainak ismerete nélkül indulnak el, sőt van olyan is, amelyet a helyi közösségek sem támogatnak. Szerintem ez elborzasztó mennyiségű pénz elpocsékolásával is együtt járhat.

De a kérdésed persze nem erről szólt. Tehát: négy évig dolgoztam tovább, folyamatosan, megbízásos jogviszonyban a Magyar Nemzeti Vidéki Hálózatban. Az Európai Unió ugyanis 2007-ben minden tagállama számára előírta, hogy az agrár-vidékfejlesztési támogatási programjaihoz egy szakemberekből és vidékfejlesztő intézményekből, vállalkozásokból álló, modern hálózati technikákat alkalmazó szervezetet kell létrehoznia. Glatz Ferenc akadémikustól vettem át ennek a ma már több mint 10000 egyéni tagot és 3000 intézményt, vidéki vállalkozást tömörítő szervezet elnökségének vezetését. A szó legszorosabb értelmében „alkalmaztam” az RKK-ban szerzett vidéktudományos és hálózatszervezési ismereteimet. Nem is gondoltam, hogy ennyi örömet hoz majd ez a közfeladat, s hogy a vidéki közösségek, szakemberek mennyire „ki vannak éhezve” a vidék- 
kel kapcsolatos új és modern tudományos ismeretekre, mennyire kreatívak, együttműködők. Több mint száz előadást tartottam, Zalaegerszegtől Nyíregyházáig, Varsótól Temesvárig. Nem kis büszkeséggel tölt el e tevékenységemhez kapcsolódva, hogy szerepem volt annak a megállapodásnak a létrehozásában, amely az MTA Közgazdaság- és Regionális Tudományi Kutatóközpontot egy igen nagy horderejü vidékkutatási megbízáshoz segítette. A Tér és Társadalom folyóirat idei első száma talán a legékesebb bizonyíték rá, hogy mennyi új eredmény született e projekt során.

\section{Shogyan látod ma az Alföld helyzetét?}

Amikor az első nagy kutatásunk befejeződött és az első független magyar kormány rendeletet alkotott az Alföldről, az itt megvalósítandó, sajátos regionális teendőkről (Határozatok tára 1994), azt hittem, valóban lesz komolyabb megújulás. Két hónapra rá, a második kormány gyorsan visszavonta, illetve „szüneteltette” ezen Alföld-rendelet végrehajtását a területfejlesztésről és -rendezésről szóló törvény elfogadásáig. Utána egyébként valóban készült több nívós stratégia és terv (pl. a Vásárhelyi-terv), de mire az uniós normák nyomán végre valóban felkészült regionális és lokális intézmények vehették volna át e fontos, az alföldi regionális sajátosságokkal is számoló feladatokat, ismét megszüntetik azokat. Sok helyi szellemi energia, sőt tervezési-szervezési tudás halmozódott fel és hasznosult már a kistérségekben, valamint a regionális fejlesztési tanácsokban, illetve azok munkaszervezeteiben, de ezeket is lassan teljesen felszámolják. Nem véletlenül írtam az első kis Alföld-kötetünk végén némi malíciával, hogy mintha a régiónk jövője múlt időben íródna (Csatári 1995). Enyedi György több mint tíz éve azt mondta egyik Alföld Kongresszusunkon, hogy e térségre nézvést három lehetséges forgatókönyv fogalmazható (Enyedi 2005). Jön a „high-tech” és felemeli a régió gazdaságát, társadalmát (majd rögtön hozzátette: ez aligha következik be). Lehetséges, hogy újjáélednek a helyi innovációk és a kevés nyersanyaghoz szellemi értéket hozzátéve a „low-tech” fog megoldást hozni. Vagy, mint mondta, egy súlyos katasztrófa ráébreszti az itt élőket, hogy nem folytatható, ami most van, és ez hoz majd - igaz kényszerüségből - alföldi regionális megújulást. Én, sajnos, ennek az utóbbinak a bekövetkezését érzékelem. Nő a klimatikus kitettségünk, a szárazodás, a szegénység, szélsőségesen és számomra riasztó mértékben növekednek a jövedelemkülönbségek. Ugyanakkor csökken a gazdaság teljesítménye (az egy Mercedes-gyár csak remélni lehet, hogy a győri Audihoz hasonló változást hoz majd), fogy és öregszik a népesség. Úgy érzem, hogy minimálisra csökkent az alföldi összetartozás érzése, vagy másképpen fogalmazva: a (területi) szolidaritás és identitás. A két alföldi tervezési régió az elmúlt évtizedben egy tapodtat sem mozdult előre az Európai Unió utolsó húsz legkedvezőtlenebb régiójának elszomorító listáján. Az interjú címéül éppen azért javasoltam Hamvas Béla egy gondolatát, mert ő aztán azt is kifejti a híres könyvecskéjében, hogy itt - ezen a „paradox” tájon - nehezebben 
vernek gyökeret az új dolgok (Hamvas 1987, 28).

Pedig a megoldások megtalálásához egyértelműen új, sokszínű „Alföld”-szellemre, sok kutatásra, professzionális tervező-fejlesztő szervezetekre, felelős közösségekre, erős szakmai és civil összefogásra, kiváló alap-, közép- és felsőfokú oktatásra, valódi helyi és regionális politikusokra volna szükség. Nyilvánvaló, hogy az a sokszínü tudás, ami az Alföld felemeléséhez kellene, jelenleg nincs a birtokunkban, s a fejlett világ regionális és vidékfejlesztési módszereinek okos és szerves alkalmazásáról is túlságosan hamar lemondtak felelős döntéshozóink. Én már ezt is - visszautalva Enyedi professzor forgatókönyveire - valóságos katasztrófának tartom.

\section{Foglalkozol-e még tudományos munkával?}

No, itt akár még definíciós kísérletbe is foghatnék, hogy mit is jelent ez a kérdés. Hagyományos értelemben tudományos munkával nem foglalkozom - tehát szervezett, intézeti kutatási keretek között, esetleg témavezetőként. Sokat olvasok és íro(gato)k is, nota bene még tanulmányokat is. Meg recenziókat. Tudományos terveim viszont vannak, de azok megvalósulásához több körülménynek változnia kellene. A magán- és a közéletemben is. Örömmel segítem és mentorálom viszont doktorandusz tanítványaimat, szívesen konzultálok volt kollegáimmal az intézet kisméretüre csökkentett kecskeméti csoportjában is. Elkel néha biztatásom, bár nem gondoltam soha, hogy ennyire érdektelen lesz a helyi vagy a megyei „politikum” a geográfia, illetve az általunk végzett tudományos munkák eredményei iránt.

Végül, a több olvasási időmben igazi gyöngyszemekre is akadok, ami nem tudományos munka ugyan, de ugyanolyan örömet okoz. Például Végel László megfogalmazása: „A nemzetállami centralizmus ellenében nem holmi brüsszeli centralizmus lebeg a szemem előtt, hanem egy bonyolultabb struktúrában gondolkodom. Ez lenne az alkotmányos regionalizmus. Ma erről szó sincs, a regionalizmust legtöbbször egyszerü kitűzőnek használjuk." Majd így folytatja: „Ha jobban megfigyeljük, a regionalizmus elevenebb hagyományokkal rendelkezik Európában, mint a nemzetállam." (Végel 2013, 12.) Igen. Én is úgy gondolom, hogy az alföldi regionális fejlesztési kudarcok fö oka, hogy itthon is és az unióban is csendes harc folyik a regionalizmus ellen. Mert nincs elég bátorsága a hatalomnak, hogy okosan megossza azt, s ezáltal képessé tegye a helyi társadalmat arra, hogy saját sorsának igazán kovácsa lehessen, mint volt az Alföldön is a mezővárosok felvirágzásának és tanyásodásának korában. Persze tudjuk: szegény ország centralizáció, gazdag ország decentralizáció. Csak az is világos, hogy a centralizáció gyakran többe kerül, s közben az érintettek elvesztik a saját jövőjük helyben való megélésének, az értelmes „ott élés”, az ott maradás és boldogulás felelős vállalásának hitét.

Talán én azért mondhatom szerencsésnek magam, mert munkáinkban és megjelent írásainkban fennmaradnak azok az eredmények, amelyek ezt kívánták elősegíteni. Hogy nem így lett, az nem a kutató hibája. A tudomány és a mü- 
vészet hazája ugyanis, mint Weöres Sándor mondta, nem a lét: az „esse”, hanem a lehetőség: a „posse”. Talán ezzel tudtam én is élni valamennyire. Nem vagyok ugyan biztos benne, de reménykedem, s abban is, hogy lesz, aki folytatja.

\section{Irodalom}

Baranyi B. (1999): A „periféria perifériáján” - a határmentiség kérdőjelei egy vizsgálat tükrében az Északkelet-Alföldön. Tér és Társadalom, 4., 17-44.

Bögre Zs., Kovács T., Tóth J. (2013): A geográfus Tóth József (1940-2013). Tér és Társadalom, 4., 209-214.

Csatári B. (1995): Az Alföld helyzete és perspektívái: Alföld kutatási program 1991-1994. 4. kötet. Nagyalföld Alapítvány, Békéscsaba

Csatári B., Farkas J. Zs. (2007): Vidéktípusok. In: Kovács Cs., Pál V. (szerk.): A társadalmi földrajz világai. Szegedi Tudományegyetem TTK Gazdaság- és Társadalomföldrajzi Tanszéke, Szeged, 103-116.

Csordás L. (1993): Szabadidő-lakások az Alföldön. Tér és Társadalom, 3-4., 75-103.

Duró A. (ed.) (1999): Spatial research in support of the European integration. The 11th Polish-Hungarian Geographical Seminar, Mátraháza. Centre for Regional Studies of the Hungarian Academy of Sciences, Pécs (Discussion Papers; special)

Enyedi Gy. (2005): Európa peremén? In: Nagy E., Nagy G. (szerk.): Az Európai Unió bővítésének kihívásai - régiók a keleti periférián. III. Alföld-kongresszus. Nagyalföld Alapítvány, Békéscsaba, 7-11.

Hamvas B. (1987): Öt géniusz. Életünk, Szombathely

Határozatok tára: Alföld-rendelet. 1994, 17., 130-136.

Kovács A. D. (2005): A környezettudatosság szerepe a Tisza-vidék fenntarthatóságában. In: Nagy E., Nagy G. (szerk.): Az Európai Unió bővitésének kihivásai - régiók a keleti periférián. III. Alföld Kongresszus. Nagyalföld Alapítvány, Békéscsaba, 132-135.

Lengyel I. (1994): A bankhálózatok kialakulásának néhány jellemzője a Dél-Alföldön. In: Blazovich L., Csatári B., Simon I. (szerk.): Alföldi Társadalom. Nagyalföld Alapítvány, Békéscsaba, 171-190.

Nagy E. (2002): A szolgáltató szektor az Alföldön. In: Csatári B., Timár J. (szerk.): Területfejlesztés, rendszerváltás és az Alföld. MTA Társadalomkutató Központ, Budapest, 106-129.

Nagy G. (2003): Regionalitás és információs társadalom. In: Nagy G., Kanalas I. (szerk.): Régiók az információs társadalomban. MTA RKK Alföldi Tudományos Intézet, Kecskemét, 77-117.

Rácz L. (1993): A történeti ökológia másik arca: A természeti környezet hatása a társadalom változásaira. Magyar Tudomány, 11., 1297-1303.

Sándor I. (2013): Demokrácia - ahol nincs. Élet és Irodalom, október 18., 12.

Timár J. (1999): Elméleti kérdések a szuburbanizációról. Földrajzi Értesítö, 1-2., 7-31.

Timár J. (2003): Problémák és perspektívák: „Mi a teendő” a kialakulóban lévő kritikai geográfia számára Magyarországon? Tér és Társadalom, 2., 53-65.

Timár J. (2005): Gender and spatial inequalities in Hungary in the transition era. In: Barta, Gy., G. Fekete, É., Szörényiné Kukorelli, I., Timár, J. (eds.): Hungarian spaces and places: Patterns of transition. Centre for Regional Studies, Pécs, 307-322.

Timár J., Nagy E., Velkey G., Nagy G., Kugler J., Duray B., Barta Gy., Beluszky P. (2012): Társadalomtudósok a „periférián”. Tér és Társadalom, 3., 151-163.

Timár J., Velkey G. (szerk.) (2003): Várossiker alföldi nézőpontból. MTA Regionális Kutatások Központja, MTA Társadalomkutató Központ, Békéscsaba, Budapest

Törökné Gémes T. (2002): Egy kutatómühely két évtizede 1982-2002: válogatott, annotált bibliográfia. MTA RKK Alföldi Tudományos Intézet, Kecskemét

Végel L. (2013): Európa-beszélgetések. Élet és Irodalom, október 25.

www.alfoldinfo.hu (Letöltés: 2015. július 1.) 